\title{
Navigating to Subsistence: The Gendered Struggles in the Postwar Everyday and Their Implications for Peace
}

Elena B. Stavrevska, London School of Economics and Political Science

In developing a feminist analysis of postwar political economic practices and institutions, my contribution builds on previous Critical Perspectives forums in following Cynthia Enloe's call $(2015,438)$ to make sense of people's gendered political lives while embracing their "messiness" and Rahel Kunz's (2017) argument for placing life stories at the center of analysis. It focuses on the everyday life of female petty traders involved in the coping economy in Bosnia and Herzegovina (BiH), including those working at the (in)famous Arizona market in Brčko. ${ }^{1}$ By taking postwar gendered everyday experiences seriously, my contribution highlights the need for a gender-just, holistic approach to designing postwar reparative justice measures, labor market interventions, and integration of coping economic practices.

The Arizona market's history stands witness to the profoundly gendered struggles in the postwar everyday. Located near the borders with Serbia and Croatia, it started as a "free-trade zone" at a roadblock created by NATO-led peacekeepers, "bringing together the warring parties." The market was both unregulated and protected, and human trafficking and prostitution soon started taking place alongside trading, with the direct involvement of peacekeepers (Haynes 2010, 1781-96). Arizona, then, was a site where dynamics about idealized militarized masculinities and prostitution (Sjoberg 2015) and conflict-related gender-based violence (Hudson 2015) played out daily.

\footnotetext{
${ }^{1}$ I remain indebted to the people with whom I spoke during my research stays near the Arizona market in June/July and November 2012, for their patience, time, and trust in sharing their knowledge and experiences. All translations from Bosnian/Croatian/Serbian are mine. The names used here are not the real names of those whose stories are presented.
} 
In 2004, this poster-child-turned-basket-case of liberal peacebuilding was rebuilt by a foreign investor, becoming a mainly regulated market. Until April 2019, when it accidentally burned down, the struggle for subsistence at Arizona (Jašarević 2007) existed within the larger macroeconomic and macrosocial postwar policies that had attempted to restrict informal economic practices rather than meaningfully integrate them. With many women depending on the informal economy during and after the war, the implications of the efforts to restrict these practices have been deeply gendered and intersectional, endangering the livelihoods of many working-class and minority women.

Fikreta traveled every day from a nearby town to Arizona. In her booth, she sold towels and clothes brought from Turkey and Hungary. Like many others, she was not a registered worker and neither paid for nor received any benefits.

I started working here in 1997 as a way to survive. It wasn't easy, but there was a lot of solidarity ... Then they modernized it and now we have to pay a fee for this, for that, and compete against all these malls ... I am not registered. My husband was a veteran, so I inherited his pension. If I get registered, I lose that. How will I survive then? Besides, my benefits can't go up before every election the way veteran pensions do. A bird in the hand is worth two in the bush. ${ }^{2}$

Indira first started trading at Arizona in 1999, selling different goods over the years. She, too, was not a registered worker. Her sister worked in the booth next to hers.

My sister convinced me to join her. Then, as my husband started drinking more, it was also good that I spent time outside the house and was earning money. He is a good man, but he hasn't been the same after the war. It changed him ... I'm not registered, but I've registered him. He used to work in a factory, ten years short of retirement when the war started. And where could he work after the war? All the factories were gone. It's different if you're a woman; you figure it out although with all the costs, it's getting harder. So I decided it was better to register him and pay benefits until he gets to retirement, so we have some certainty for the future. ${ }^{3}$

\footnotetext{
2 Personal interview, Arizona, June 19, 2012.

${ }^{3}$ Personal interview, Arizona, June 25, 2012.
} 
Fikreta's and Indira's stories resonated with the experiences of other female petty traders, especially those who self-identified with the three constituent peoples. Notably, the BiH Constitution only recognizes Bosniaks, Croats, and Serbs as constituent peoples, while other minorities remain institutionally marginalized. In a divided and patriarchal society, as part of a minority that is also the country's poorest, Romani women face triple interlocking oppression. Economic opportunities for Roma remain hard to find because of racial prejudice, inadequate training, and lack of education, with their formal employment rate at a mere $11 \%$ and their informal sector participation at 63\% (quoted in Tulumovic 2018, 15). Most Romani women in $\mathrm{BiH}$ are unregistered workers, often selling goods or offering cleaning services or working within the household to provide care for family members.

These women's experiences highlight the intersectional aspects of the postwar policies in $\mathrm{BiH}$. One of those experiences is Sanela's, who makes a living by producing and selling tomatoes at local markets and cleaning houses. She, too, is not a registered worker.

"Are you 'ours'?" This is what everybody asked. And the Roma, we were nobody's, left on our own. How much we suffered, that didn't count ... My family hasn't been able to claim any reparations or restitutions. We don't have the paperwork. And nobody wants to help, nobody needs Roma votes ... I clean houses and sell tomatoes. You have to find a way to help the family, but without education and with all the stereotypes, what job could I get? With the cleaning, you go to people's houses, you clean, you get paid. Nobody even knows you are there. But with the tomatoes, sometimes I have a hard time with inspectors for being unregistered ... probably for being a Roma too. If I were to get registered, we wouldn't be able to survive. ${ }^{4}$

Making sense of the messiness of postwar everyday life, some important points emerge.

First, certain socioeconomic measures, even though they are intended to complement transitional justice and peace efforts, such as reparations, can create additional social cleavages (Hronešová 2016) and exacerbate gender inequality if not approached holistically (see Daniela Lai's

\footnotetext{
${ }^{4}$ Personal interview, Brčko, June 22, 2012.
} 
contribution to this forum). $\mathrm{BiH}$ offers material reparations to war veterans and civilian victims. Officially, the first far outnumber the second. Having political representation restricted to the three constituent peoples, veteran organizations of the three ethnicities have gotten higher socioeconomic support in exchange for electoral endorsement (Hronešová 2016). Without other corresponding measures in place in a weak economy, this mechanism contributes to women and children being dependent on the pension of a male family member, as is the case with Fikreta, or not having access to reparative justice mechanisms, as is the case with Sanela and Romani people, whose suffering is hardly recognized at all (Sardelić 2017).

Second, with $\mathrm{BiH}$ as the center of Yugoslavia's metal industry, its destruction further reshaped labor and gender relations in the country. Only a small part of that industry has been revitalized and privatized since, often in a questionable manner, leaving a large portion of the labor force without jobs. These processes, supported through International Financial Institutions' interventions, together with the patriarchal beliefs that women are more flexible and resilient, as in Indira's case, have pushed many women to seek subsistence in the informal economy or microcredit businesses, sometimes making them the sole family breadwinner and affecting gender and family dynamics in important ways (Stavrevska 2018).

Finally, Indira, Sanela, and Fikreta note how the attempt to regulate the informal economy adds a financial burden in their efforts to navigate to subsistence. This regulation of the coping economy has been unfolding in parallel to the country's integration in the largely deregulated global market, so some traders have also mentioned the challenge their livelihoods face with foreign investors building shopping malls nearby. This emphasizes the connection between the postwar everyday and global processes. Sanela's case, on the other hand, is a 
poignant reminder of the racial marginalization that has been exacerbated by the war and subsequent neoliberal policies.

Fikreta's, Indira's, and Sanela's life stories highlight the forms of violence they face and the ways in which they exercise their agency. They also show the postwar everyday as a site of continuous contestation over women's appropriate roles in economic and family life and a site where neoliberal reforms reshape people's lives (Elias and Roberts 2016, 794), highlighting how everyday acts and forms of violence connect to global political economic systems (Elias and Rai 2015, 426). At the same time, the postwar everyday, understood in its historical and global context, is not only a critical site in rebuilding bridges between feminist political economy and feminist security studies, but also a site of local knowledges, offering invaluable insights into the challenges to sustainable and inclusive peace and demonstrating the necessity for peace studies to center feminist scholarship in its understanding of the everyday.

$<\mathrm{BIO}>$ Elena B. Stavrevska is a Research Officer in the Centre for Women, Peace and Security at the London School of Economics and Political Science: E.Stavrevska@lse.ac.uk

\section{REFERENCES}

Elias, Juanita, and Shirin Rai. 2015. “The Everyday Gendered Political Economy of Violence.” Politics \& Gender 11(2): 424-29.

Elias, Juanita, and Adrienne Roberts. 2016. "Feminist Global Political Economies of the Everyday: From Bananas to Bingo." Globalizations 13 (6): 787-800. 
Enloe, Cynthia. 2015. "Closing Remarks: Militiamen Get Paid; Women Borrowers Get Beaten.” Politics \& Gender 11 (2): 435-38.

Haynes, Dina Francesca. 2010. “Lessons from Bosnia's Arizona Market: Harm to Women in a Neoliberalized Postconflict Reconstruction Process." University of Pennsylvania Law Review 158: 1779-2010.

Hronešová, Jessie. 2016. “Might Makes Right: War-Related Payments in Bosnia and Herzegovina." Journal of Intervention and Statebuilding 10 (3): 339-60.

Hudson, Heidi. 2015. “(Re)framing the Relationship between Discourse and Materiality in Feminist Security Studies and Feminist IPE." Politics \& Gender 11 (2): 413-19. Jašarević, Larisa. 2007. “Everyday Work: Subsistence Economy, Social Belonging and Moralities of Exchange at a Bosnian (Black) Market.” In The New Bosnian Mosaic: Identities, Memories and Moral Claims in a Post-War Society, eds. Xavier Bougarel, Elissa Helms, and Ger Duijzings. Burlington, VT: Ashgate, 273-94.

Kunz, Rahel. 2017. “Beyond the 'Helpless Nepali Woman' versus the 'Fierce Maoist Fighter': Challenging the Artificial Security/Economy Divide." Politics \& Gender 13 (4): 733-39. Sardelić, Julija. 2017. "Romani Minorities in War Conflicts and Refugee Crises of the (Post)Yugoslav Space: A Comparative Socio-Historical Perspective.” Roma Rights: Journal of the European Roma Rights Centre 1 (1): 35-41.

Sjoberg, Laura. 2015. "From Unity to Divergence and Back Again: Security and Economy in Feminist International Relations." Politics \& Gender 11 (2): 435-38.

Stavrevska, Elena. 2018. “The Mother, the Wife, the Entrepreneur? Women's Agency and Microfinance in a Disappearing Post-Conflict Welfare State Context." Civil Wars 20 (2): $193-216$. 
Tulumovic, Rasim. 2018. Potentials for Roma Employment in the Enlargement Region. Belgrade: Regional Cooperation Council Roma Integration 2020 Action Team. 